\title{
KNOWLEDGE, OPINIONS AND ATTITUDES OF FEMALE STUDENTS AND THEIR MOTHERS ABOUT HUMAN PAPILLOMA VIRUS VACCINE
}

\author{
Dilek MENEKŞE ${ }^{1}$, Nursan ÇINAR ${ }^{2}$ \\ 1-2 Sakarya Üniversitesi, Sağlık Bilimleri Fakültesi, Çocuk Sağlı̆̆ ve Hastalıkları Hemşireliği Anabilim Dalı, \\ Sakarya / Türkiye
}

ORCID ID:0000-0003-0176-87781, 0000-0003-3151-9975²

Öz: Amaç: Bu çalışma, Sağlık yüksekokulu son sınıf kız öğrencilerinin ve annelerinin Human Papilloma Virüs (HPV) Așısı hakkında bilgi, görüş ve tutumlarının belirlenmesi amacıyla yapıldı. Yöntem: Tanımlayıcı tipte planlanan çalışmanın evrenini 2014-2015 yılı bahar yarıyılında Sakarya ilinde bir sağlık yüksekokulunun hemşirelik ve ebelik bölümünde öğrenim gören 4. sınıf kız öğrencilerin tamamı, örneklemini ise ça1ışmaya katılmayı kabul eden $63 \mathrm{kız}$ öğrenci ve anneleri oluşturmuştur. Veriler, araştırmacılar tarafından geliştirilen öğrenci soru formu ve anne soru formu ile toplanmıştır. Elde edilen veriler bilgisayar ortamında yüzdelik ve ortalama kullanılarak değerlendirilmiştir. Bulgular: Çalışmaya katılan öğrencilerin yaş ortalaması $21,65 \pm 0,91$ olarak belirlenmiştir. Öğrencilerin \%87,3'ünün HPV ve \%88,9'unun HPV aşısı hakkında bilgisinin olduğu belirlenmiştir. Çalışmaya katılan kız öğrencilerden sadece birinin HPV aşısını yaptırdığı, HPV aşısı olmayanların $\% 39,7$ 'sinin aşı olmak istedikleri, \%6,3'ünün eğer aşı ücretsiz olursa olmak istediği, \%34,9'unun aşı hakkında daha fazla bilgiye ihtiyacı olduğu ve \%17,5'inin bu konuda emin olmadığını ifade ettiği bulunmuştur. Annelerin; \% 15,9 'u HPV aşı1S1 hakkında bilgisi olduğunu belirtmiştir. Eğer imkanı olsaydı, $\% 52,4$ 'ü aşı olmak istediğini, \%47,6'sı kararsız olduğunu ifade etmiștir. Sonuç: Kız öğrencilerin ve annelerinin HPV ve HPV aşısı hakkındaki bilgilerinin yeterli olmadığı saptanmıştır.

Anahtar Kelimeler HPV, Aşı, Kadın, Rahim, Öğrenci, Kanser
Abstract: Aim: This study was carried out to determine the knowledge, opinions and attitudes of final year female students of a Vocational Health High School and their mothers on Human Papilloma Virus (HPV) Vaccination. Method All 4th grade female students studying in the nursing and midwifery department of a vocational health high school in Sakarya Province during the 2014-2015 spring term constituted the population of the study which was designed as a descriptive type. Sample 63 female students and their mothers who agreed to participate in the study. Data were collected using the student questionnaire form and mother questionnaire form developed by the researchers. The data obtained were evaluated using percentage and mean in the computer environment. Results: All of the students participating in the study were female and the average age was $21.65 \pm 0.91 .87 .3 \%$ of the students $(\mathrm{n}=55)$ reported that they had knowledge about HPV, $88.9 \%$ of them $(n=59)$ reported that they had knowledge about HPV vaccine. It was determined that $1.6 \%$ of the female students participating in the study $(\mathrm{n}=1)$ had $\mathrm{HPV}$ vaccination. $39.7 \%$ of those who did not have HPV vaccine stated that they wanted to be vaccinated, $6.3 \%$ of them $(n=4)$ stated that they wanted to be vaccinated if the vaccine would free, $34.9 \%$ of them $(n=22)$ stated that they needed more knowledge about the vaccine, and $17.5 \%$ of them $(n=11)$ stated that they were not sure about it. $15.9 \%$ of the mothers $(n=10)$ indicated that they had knowledge about HPV vaccine. $52.4 \%$ of mothers $(n=33)$ stated that they wanted to be vaccinated and $47.6 \%$ of them $(n=30)$ stated that they were undecided if there was the possibility of being vaccinated. Conclusion: It was determined that the knowledge of the mothers of female students about HPV and HPV vaccine was not adequate.

Key Words: HPV, Vaccine, Woman, Uterus, Student, Cancer

Doi: 10.17363/SSTB.2019.31.7

(1) Sorumlu Yazar: Dilek MENEKŞE, Sakarya Üniversitesi, Sağllk Bilimleri Fakültesi, Sakarya / Türkiye, dkose@ sakarya.edu.tr, Geliş Tarihi/Received: 18.01.2019, Kabul Tarihi/Accepted: 11.06.2019, Makalenin Türü: Type of Article (Araştırma ve Uygulama / Research and Application) Çıkar Çatışması / Conflict of Interest: Yok / None "Etik Kurul Raporu Yok /None 
International Refereed Academic Journal of Sports, Health and Medical Sciences April - May - June Issue: 31 Spring Summer Semester Year: 2019

Uluslararası Hakemli Akademik Spor Sağlık ve Tıp Bilimleri Dergisi

Nisan - Mayıs - Haziran Sayı: 31 İlbahar Yaz Dönemi Yıl: 2019 ID:436 K:528

ISSN Print: 2146-8508 Online 2147-1711

(ISO 18001-OH-0090-13001706 / ISO 14001-EM-0090-13001706 / ISO 9001-QM-0090-13001706 / ISO 10002-CM-0090-13001706) (TRADEMARK)

(2015/04315- 2015-GE-18972)

\section{GíRiş}

Önlenebilir hastalıklardan biri olan servikal kanser, önemli bir sağlık sorunudur. Dünyada kadınlar arasında servikal kanser üçüncü yaygın kanser türü olup 2018 y1lında 569.847 kişiye yeni tanı koyulmuş, 311.365 kişinin bu nedenle kaybedildiğgi/öldüğü bildirilmiştir (Bray et al., 2018: 398). Ülkemizde Sağlık Bakanlığının 2015 Kanser verilerine göre serviks kanseri tüm kadın kanserleri içinde dokuzuncu sırada yer almaktadır (T.C. Sağlık Bakanlığı, 2018: 20). Human Pallioma Virüs (HPV) servikal kanserin en s1k nedenlerinden biridir. HPV'nin baş boyun kanserlerinde olduğu gibi diğer anogenital kanserlerde de (anüs, vulva, vajina ve penis) ilgili bir faktör olduğuna dair kanıtların olduğu bildirilmiştir (Bruni et al., 2018: 5). Kadın, erkek ve her yaş grubunda görülebilen bu kanser türü özellikle 9-26 yaş arası cinsel yönden aktif olan gençler/bireyler için önemli risk grubunu oluşturmaktadır (Tezer vd., 2013: 89-92).

Servikal kanseri önleme yöntemleri ile birlikte HPV farkındalığı ve profiklaktik aşı uygulaması, servikal kanser insidansını ve ölümleri önemli derecede azaltmaktadır ((Bray et al., 2018: 420).T.C. Sağlık Bakanlığı, 2018: 2427). Günümüzde profilaktik aşı uygulaması; HPV 16 ve 18 enfeksiyonlarına karşı geliştirilen bivalan, HPV 6 ve 11 enfeksiyonuna karşı geliştirilen kuadrivalan ve HPV 6, 11, $16,18,31,33,45,52$ ve 58 enfeksiyonlarına karşı geliştirilen nonavalent olmak üzere üç aş1 üzerinden yürütülmektedir (Printz, 2015: 1156-1157; WHO, 2017: 249 ). Hem k1z hem erkeklerde kullanılan bivalan, kuadrivalan ve nonavalent HPV aşılarının şu an için koruyuculuk süresinin beş yıl olduğu bildirilmektedir (Tezer vd., 2013: 89-92). Aş1 31 Mart 2017'den itibaren kızlar için 71 ülkede ve erkekler için 11 ülkede rutin aşı takviminde olup yaygın olarak kullanıyor olmasina rağmen Türkiye'de ulusal aşı takviminde yer almamaktadır. Aş1 ücretli olup uygulanması ailenin isteğine bağlıdır (WHO, 2017: 248; Kürtüncü vd., 2018: 1076).

HPV aşısının uygulanabilmesi ve aşının toplum tarafindan kabul edilmesinde en önemli faktör şüphesiz sağlık profesyonellerinin bilgi tutum ve yaklaşımlarıdır. Serviks kanserinden korunma yolları, tarama testleri ve HPV aşısı konusunda toplumun farkındalığını arttırmak, toplumu bilinçlendirmek ve olumlu sağlık davranışlarını geliştirmek için sağlık profesyonellerinin öncelikle bu konudaki kendi bilgi ve tutumları önem taşımaktadır (Dönmez et al., 2018: 1-2). Yapılan çalışmalar, sağlık personelinin HPV aşılarını destekliyor ve öneriyor olmasının, aşının kabul edilebilirliğini artıran ana neden olduğunu göstermektedir (Madhivanan et al., 2014: 109; Demirel Bozkurt vd., 2016: 31). Sağlık profesyonelleri kadar adolesanların annelerinin aşı konusunda bilgi, tutum ve kararlarının etkili olduğu 
International Refereed Academic Journal of Sports, Health and Medical Sciences April - May - June Issue: 31 Spring Summer Semester Year: 2019

Uluslararası Hakemli Akademik Spor Sağlık ve Tıp Bilimleri Dergisi

Nisan - Mayıs - Haziran Sayı: 31 İlbahar Yaz Dönemi Yıl: 2019 ID:436 K:528

ISSN Print: 2146-8508 Online 2147-1711

(ISO 18001-OH-0090-13001706 / ISO 14001-EM-0090-13001706 / ISO 9001-QM-0090-13001706 / ISO 10002-CM-0090-13001706) (TRADEMARK)

bildirilmektedir (Kose et al., 2014:7266; Berenson et al., 2014:1087). Özellikle annelerin hastalık ve aşı hakkındaki temel bilgileri, aşılama programının başarısı için temel etkendir.

$\mathrm{Bu}$ bilgiler doğrultusunda bu çalışma, hem geleceğin sağlık profesyonelleri olacak son sınıf hemşirelik, ebelik öğrencilerinin hem de annelerinin HPV aşısı hakkındaki bilgi ve tutumlarını belirlemek amaçlı planlanmıştır. Bu çalışma 1) Hemşirelik ve ebelik kız öğrencilerinin HPV aşısı hakkında bilgi, görüş ve tutumu nedir? 2) Hemşirelik ve ebelik kız öğrencilerinin HPV aşılanma oranı nedir? 3) Kız öğrencilerinin HPV aşısı hakkında bilgisi nedir? Annelerin kızlarına HPV aşısı yaptırma konusundaki düşüncesi nedir? sorularına cevap aramaktadır.

\section{YÖNTEM}

\section{Araştırmanın Amacı ve Tipi}

Bu çalışma, Sağlık yüksekokulu son sınıf kız öğrencilerinin ve annelerinin HPV aşılaması hakkında bilgi, görüş ve tutumlarının belirlenmesi amacıyla tanımlayıcı olarak yapıldı.

\section{Araştırmanın Yapıldığı Yer ve Zaman}

Türkiye'nin kuzeybatısında yer alan Sakarya ilinde bulunan bir üniversitenin sağlık yüksekokulunda Şubat 2015'te başlayan araştırma Nisan 2015'te tamamland.

\section{Araştırmanın Evren ve Örneklemi}

Çalışmanın evrenini 2014-2015 yılı bahar yarıyılında Sakarya ilinde bir sağlık yüksekokulunun hemşirelik ve ebelik bölümünde öğrenim gören 4. sınıf kız öğrencilerin tamamı oluşturdu. Araştırmanın yapıldığ 144 öğrenci son sınıfta öğrenim görmekte idi. Örneklem hesabı yapılmayıp, evrenin tamamına ulaşılması hedeflendi. Çalışmaya katılmayı kabul eden soru formlarını düzgün ve eksiksiz doldurup araştırmacıya ulaştıran 63 k1z öğrenci ve anneleri (okuma yazması olan) araştırma kapsamına alındı (Katılma oranı: \% $43,75)$.

\section{Veri Toplama Araçları}

Veriler konu ile ilgili literatür (Tezer vd., 2013: 89-92; Kose et al., 2014:7263-7266) incelenerek araştırmacılar tarafından geliştirilen öğrenci soru formu ve anne soru formu ile toplandi.

\section{Öğrenci Soru Formu}

Öğrenci soru formu sosyodemografik bilgilerin yer aldığı (yaş, okuduğu bölüm, medeni durum, çalışma durumu, ekonomik durum vb.) 6 soru ve öğrencilerin HPV aşısı ile ilgili bilgi ve tutumlarını (HPV aşısını bilme, aşının kaç doz, kime, hangi yaşta yapılacağı, koruyuculuk süresi vb.) belirleyen 13 soru olmak üzere toplam 19 sorudan oluşmakta idi. 
International Refereed Academic Journal of Sports, Health and Medical Sciences

April - May - June Issue: 31 Spring Summer Semester Year: 2019

Uluslararası Hakemli Akademik Spor Sağlık ve Tıp Bilimleri Dergisi

Nisan - Mayıs - Haziran Sayı: 31 İlbahar Yaz Dönemi Yıl: 2019 ID:436 K:528

ISSN Print: 2146-8508 Online 2147-1711

(ISO 18001-OH-0090-13001706 / ISO 14001-EM-0090-13001706 / ISO 9001-QM-0090-13001706 / ISO 10002-CM-0090-13001706) (TRADEMARK)

(2015/04315- 2015-GE-18972)

\section{Anne Soru Formu}

Toplamda 26 sorudan oluşan anne soru formunda sosyo demografik bilgiler ile ilgili 6 soru, HPV bilgi ve tutumları (HPV aşısını duyma ve yaptırma, aşının hangi yaşta, kime yapılacağı, çocuklarına yaptırma durumu vb.) ile ilgili 20 soru yer almakta idi.

\section{Verilerin Toplanması}

Çalışma hakkında bilgi verildikten sonra çalışmaya katılmaya gönüllü olan öğrencilere Öğrenci Soru Formu ve Anne Soru Formu numaraları aynı rakam olacak şekilde eşleştirilerek öğrenci soru formu dağıtıldı. Öğrenciler, soru formunu sinif ortamında doldurdu. Öğrencilerin soru formunu doldurma işlemi 10 dakika sürdü. Annelere kızları aracılığıyla kapalı zarf yöntemi ile gönüllü olur formu ve anne soru formu gönderildi. Anneler soru formunu doldurduktan sonra kapalı zarfla araştırmacılara gönderdi. Annelerden gelen verilerin tamamlanması yaklaşık iki ay sürdü.

\section{Araştırmanın İzni}

Uygulamaya başlamadan önce araştırmanın yapıldığı kurumdan yazılı izin alındı. Veri toplanmadan önce öğrencilere çalışmanın amacı ve soru formu hakkında bilgi verilerek sözlü onayları alındı. Annelere çalışmanın amacını, cevapların gizliliği, verilerin nerede ve nasıl saklanacağı hakkında bilgi içeren gönüllü olur formu kapalı zarf içinde gönderilerek çalışmaya katılan annelerden yazılı onayları alındı.

\section{Verilerin Değerlendirilmesi}

Elde edilen veriler bilgisayar ortamında sayı, yüzdelik ve ortalama kullanılarak değerlendirildi. (IBM, SPSS statistics 20, SPSS 20, Inc. An IBM Corp., Armonk, NY).

\section{BULGULAR}

\section{Kız öğrencilerin ve annelerin sosyodemog- rafik özelliklerine ilişkin bulgular}

Çalışmaya katılan kız öğrencilerin \%69,8'i $(n=44)$ hemşirelik, \%30,2'si $(n=19)$ ebelik bölümü öğrencisi olup yaş ortalaması $21,65 \pm 0,91(\min =20, \max =25)$ olarak belirlendi. Öğrencilerin \%90,5'inin çalışmadığ 1 , $\% 98,4$ 'ünün bekar olduğu ve \%66,7'sinin ekonomik durumunu orta olarak tanımladığ 1 belirlendi. Çalışmaya katılan kız öğrencilerin annelerinin yaş ortalaması 46,78 $\pm 5,74$ $(\min =36 \max =59)$ 'dır. Annelerin çoğunlukla (\%73'ünün) ( $n=46)$ ilköğretim mezunu olduğu, \%88,9'unun çalışmadığı saptandı (Tablo $1)$. 
International Refereed Academic Journal of Sports, Health and Medical Sciences April - May - June Issue: 31 Spring Summer Semester Year: 2019

Uluslararası Hakemli Akademik Spor Sağlık ve Tıp Bilimleri Dergis

Nisan - Mayıs - Haziran Sayı: 31 İlbahar Yaz Dönemi Yıl: 2019 ID:436 K:528

ISSN Print: 2146-8508 Online 2147-1711

(ISO 18001-OH-0090-13001706 / ISO 14001-EM-0090-13001706 / ISO 9001-QM-0090-13001706 / ISO 10002-CM-0090-13001706) (TRADEMARK)

(2015/04315- 2015-GE-18972)

Tablo 1. Kız öğrencilerin ve Annelerinin Sosyodemografik Özelliklerine Göre Dağılımları

\begin{tabular}{|c|c|c|}
\hline Sosyodemografik özellikler & Kız Öğrenci (n=63) & $\begin{array}{l}\text { Anne } \\
(n=63)\end{array}$ \\
\hline \multirow[t]{2}{*}{$\begin{array}{l}\text { Yaş }(\text { Ort } \pm S S) \\
(\min , \max )\end{array}$} & $\begin{array}{l}21,65 \pm 0,91 \\
(\min =20, \max =25)\end{array}$ & $\begin{array}{l}46,78 \pm 5,74 \\
(\min =36 \max =59)\end{array}$ \\
\hline & $\mathrm{n}(\%)$ & $\mathrm{n}(\%)$ \\
\hline \multicolumn{3}{|l|}{ Bölüm } \\
\hline Hemşirelik & $44(69,8)$ & - \\
\hline Ebelik & $19(30,2)$ & - \\
\hline \multicolumn{3}{|l|}{ Medeni durum } \\
\hline Bekar & $62(98,4)$ & - \\
\hline Evli & $1(1,6)^{* *}$ & $63(100)$ \\
\hline \multicolumn{3}{|l|}{ Eğitim Durumu } \\
\hline Okur-yazar & - & $5(7,9)$ \\
\hline İlköğretim mezunu & - & $46(73)$ \\
\hline Lise mezunu & - & $10(15,9)$ \\
\hline Üniversite mezunu & $-*$ & $2(3,2)$ \\
\hline \multicolumn{3}{|c|}{ Ekonomik durum (Kendi ifadesine göre) } \\
\hline Gelir Giderden az & $1(1,6)$ & $1(1,6)$ \\
\hline Gelir gidere eşit & $41(65,1)$ & $44(69,8)$ \\
\hline Gelir giderden fazla & $21(33,3)$ & $18(28,6)$ \\
\hline \multicolumn{3}{|l|}{ Çalışma Durumu } \\
\hline Çalışıyor & $6(9,5)$ & $7(11,1)$ \\
\hline Çalışmıyor & $57(90,5)$ & $56(88,9)$ \\
\hline
\end{tabular}

*Lisans 4. Sınıf öğrencisi ** Çocuğu yok

Kız Öğrenciler ve Annelerinin HPV Așısı Hakkındaki Bilgi Durumlarına İlişkin Bulgular

Öğrencilerin \% 4,8 'i birincil derecede akrabalarında serviks kanseri olduğunu bildirdi. Öğrencilerin \%87,3'ünün HPV ve \%88,9'unun HPV aşısı hakkında bilgisinin olduğu, bu bilgileri çoğunlukla $(\% 76,2)$ şu an okudukları yüksekokuldaki mesleki eğitimleri sırasında edindikleri bulunmuştur. Diğer bilgi kaynakları ise; sirasiyla en yüksek oranda internet $(\% 28,6)$ sağlık personeli (doktor, hemşire vb.) $(\% 17,5)$ 'dir. Öğrencilerin \%33,3'ü aş1nın kız çocuklarına, \%30,2'si hem kız hem de erkek çocuklarına, \%39,7'si 10-18 yaş arasında yapıldığını bildiğini ifade etmiştir. Öğrencilerin \%31,7'si aşının toplamda üç doz yapıldığını bildirmiş, yalnızca \%12,7'si- 
International Refereed Academic Journal of Sports, Health and Medical Sciences

April - May - June Issue: 31 Spring Summer Semester Year: 2019

Uluslararası Hakemli Akademik Spor Sağlık ve Tıp Bilimleri Dergisi

Nisan - Mayıs - Haziran Sayı: 31 İlbahar Yaz Dönemi Yıl: 2019 ID:436 K:528

ISSN Print: 2146-8508 Online 2147-1711

(ISO 18001-OH-0090-13001706 / ISO 14001-EM-0090-13001706 / ISO 9001-QM-0090-13001706 / ISO 10002-CM-0090-13001706) (TRADEMARK)

(2015/04315- 2015-GE-18972)

nin aşının koruyuculuk süresini doğru bildiği saptanmıştır (Tablo 2).

Annelerin \% 77,8'inin daha önceden pap smear testini duyduğu, \%6,3'ünün ailesinde ve yakın çevresinde serviks kanseri olduğu, bunların \%4,'ünün birincil derece ve \%1,6'sının ikincil dereceden akraba olduğu belirlenmiştir. Annelerin sadece \%11,1'inin HPV hakkında bilgilerinin olduğu ve \%9,5'inin HPV enfeksiyonun cinsel yolla bulaştığını bildirdi.
Annelerin \%15,9'u HPV aşısı hakkında bilgisi olduğunu, bilgisi olanların da $\% 9,5$ 'i bu bilgiyi sağlık personelinden, \%3,2'si televizyon, gazete, radyodan ve \%3,2'si akraba arkadaştan aldığ1 saptanmıştır.

Annelerin \%66,7'sinin HPV aşısının kimlere yapıldığını, \%85,7'sinin hangi yaşta yapıld1ğını, \%92,1'inin aşının kaç doz yapıldı̆̆ını, \%93,7'sinin koruyuculuk süresinin kaç y1l olduğunu bilmediği belirlendi (Tablo 2).

Tablo 2. Kız Öğrencilerinin ve Annelerinin HPV ve HPV Aşısı Hakkındaki Bilgilerine Göre Dă̆ılımı

\begin{tabular}{lll} 
& $\begin{array}{l}\text { Kız Öğrenci } \\
(\mathrm{n}=63)\end{array}$ & $\begin{array}{c}\text { Anne } \\
(\mathrm{n}=63)\end{array}$ \\
\cline { 2 - 3 } & $\mathrm{n}(\%)$ & $\mathrm{n}(\%)$ \\
\hline Aile veya yakın çevresinde serviks kanseri olma durumu & & \\
Evet & $3(4,8)^{*}$ & $4(6,3)^{* *}$ \\
Hayır & $60(95,2)$ & $59(93,7)$ \\
\hline HPV bilme durumu & & \\
Biliyor & $55(87,3)$ & $7(11,1)$ \\
Bilmiyor & $8(12,7)$ & $56(88,9)$ \\
\hline HPV aşısını bilme durumu & & \\
Biliyor & $56(88,9)$ & $10(15,9)$ \\
Bilmiyor & $7(11,1)$ & $53(84,1)$ \\
\hline HPV ve HPV aşısı hakkında bilgi kaynağı *** & & - \\
Mesleki eğitim sirasında & $48(76,2)$ & $6(9,5)$ \\
Sağlık personeli (doktor, hemşire vb.) & $11(17,5)$ & - \\
İnternet & $18(28,6)$ & $2(3,2)$ \\
Televizyon, Radyo ve Gazete & $2(3,2)$ & $2(3,2)$ \\
Arkadaş- Akraba & $3(4,8)$ & \\
\hline
\end{tabular}


International Refereed Academic Journal of Sports, Health and Medical Sciences April - May - June Issue: 31 Spring Summer Semester Year: 2019

Uluslararası Hakemli Akademik Spor Sağlık ve Tıp Bilimleri Dergisi

Nisan - Mayıs - Haziran Sayı: 31 İlbahar Yaz Dönemi Yıl: 2019 ID:436 K:528

ISSN Print: 2146-8508 Online 2147-1711

(ISO 18001-OH-0090-13001706 / ISO 14001-EM-0090-13001706 / ISO 9001-QM-0090-13001706 / ISO 10002-CM-0090-13001706) (TRADEMARK)

\section{HPV aşısı kime yapıldığını bilme durumu}

Kız çocuklara

Erkek çocuklara

Hem kız hem erkek çocuklarına

Evli kadınlara

Bilmiyor

$\begin{array}{ll}21(33,3) & 5(7,9) \\ - & 1(1,6) \\ 19(30,2) & 2(3,2) \\ 15(23,8) & 13(20,6) \\ 8(12,7) & 42(66,7)\end{array}$

HPV aşısı hangi yaşta yapıldığını bilme durumu 9 yaşından küçüklere

$8(12,7)$

$25(39,6)$

$11(17,5)$

$19(30,2)$
$2(3,2)$

$5(7,9)$

$2(3,2)$

$54(85,7)$

\section{HPV aşısı kaç dozda yapıldığını bilme durumu}

$1 \mathrm{doz}$

$2 \mathrm{doz}$

$3 \mathrm{doz}$

$4 \mathrm{doz}$

Bilmiyor

$3(4,8)$

*Birincil derece akraba $(\mathrm{n} ; \%)=3 ; 4,8$

** Birincil derece akraba $(\mathrm{n} ; \%)=3 ; 4,8$ İkincil derece akraba $(n ; \%)=1 ; 1,6$

***Birden fazla işaretleme yapılmıştır.

\section{Kız Öğrenciler ve Annelerinin HPV Aşısı} Hakkındaki Görüş ve Tutumlarına İlişkin

\section{Bulgular}

Çalışmaya katılan kız öğrencilerin \%1,6's1nın (n=1) HPV aşısını yaptırdı ̆̆1, \%98,4'ünün $(\mathrm{n}=62)$ yaptırmadığı belirlendi (Grafik 1). HPV aşısı olmayanların \%40,3'ünün aşıyı olmak istedikleri, \%6,5'inin $(n=4)$ eğer aşı ücretsiz olursa olmak istedikleri, \%35,5'inin $(n=22)$ aşı hakkında daha fazla bilgiye ihtiya-
$5(7,9)$

$20(31,8)$

$5(7,9)$

$30(47,6)$

$\begin{array}{ll}8(12,7) & 4(6,3) \\ 55(87,3) & (93,7)\end{array}$

c1 olduğunu ve \%17,7'sinin (n=11) bu konuda emin olmadığ 1 belirlenmiştir. "HPV aşısı olma konusunda annenizin görüşü sizce nedir?" sorusuna öğrencilerin \% 96,8'i $(\mathrm{n}=61)$ kararı bana bırakır cevabını vermiştir. "Siz çocuk sahibi olduğunuzda çocuğunuza HPV aşısı yaptırmak ister miydiniz?" sorusuna \%57,1'inin $(n=36)$ oranında evet olarak cevap verdiği saptanmıştır.

Çalışmaya katılan annelerin tümü HPV aşısı olmadıklarını belirtmiştir (Grafik 1). Eğer aşı olma imkanı olsaydı \%52,4'ü (n=33) olmak istediklerini ve \%47,6's1 (n=30) kararsiz olduklarını bildirmiştir. Annelere "Çocuklarınıza HPV aşısını yaptırdınız mı? sorusuna 

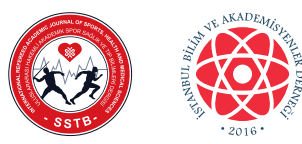

SSTB

www.sstbdergisi.com

International Refereed Academic Journal of Sports, Health and Medical Sciences

April - May - June Issue: 31 Spring Summer Semester Year: 2019

Uluslararası Hakemli Akademik Spor Sağlık ve Tıp Bilimleri Dergisi

Nisan - Mayıs - Haziran Sayı: 31 İlbahar Yaz Dönemi Yıl: 2019 ID:436 K:528

ISSN Print: 2146-8508 Online 2147-1711

(ISO 18001-OH-0090-13001706 / ISO 14001-EM-0090-13001706 / ISO 9001-QM-0090-13001706 / ISO 10002-CM-0090-13001706) (TRADEMARK)

(2015/04315- 2015-GE-18972)

bir annenin \%1,6 $(n=1)$ oranında kız çocuğuna aşı yaptırdığı belirlenmiştir. "Kızınızın rahim ağzı kanserini önlemeye yönelik aşı yaptırma konusunda düşünceniz nedir?" sorusuna annelerin \%92,1'i (n=58) aldığı eğitimden dolayı kendi kararını kendi vermesini daha doğru olacağını ifade ettikleri belirlenmiştir (Tablo 3).

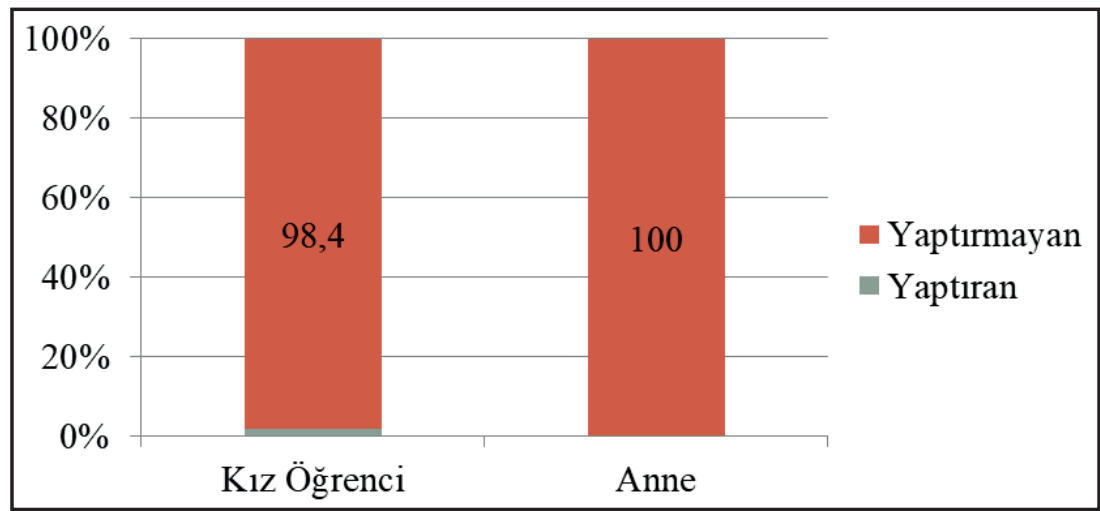

Grafik 1. Kız Öğrencilerin ve Annelerinin HPV Așısı Yaptırma Oranı 
International Refereed Academic Journal of Sports, Health and Medical Sciences

April - May - June Issue: 31 Spring Summer Semester Year: 2019

Uluslararası Hakemli Akademik Spor Sağlık ve Tıp Bilimleri Dergis

Nisan - Mayıs - Haziran Sayı: 31 İlbahar Yaz Dönemi Yıl: 2019 ID:436 K:528

ISSN Print: 2146-8508 Online 2147-1711

(ISO 18001-OH-0090-13001706 / ISO 14001-EM-0090-13001706 / ISO 9001-QM-0090-13001706 / ISO 10002-CM-0090-13001706) (TRADEMARK)

(2015/04315- 2015-GE-18972)

Tablo 3. Kız Öğrenciler ve Annelerinin HPV Aşısı Hakkındaki Görüşlerine Göre Dağılımı

\begin{tabular}{ll}
\multicolumn{1}{c}{$\mathrm{n}$} & $\mathrm{n}(\mathbf{\%})$ \\
\hline HPV aşısı olmayan kız öğrencilerin aşı olma isteği (Kız Öğrenciler, n=62) & $25(40,3)$ \\
Aşı olmak isterim. & $4(6,5)$ \\
Eğer aşı ücretsiz olursa olmak isterim. & $22(35,5)$ \\
Aşı hakkında daha fazla bilgiye ihtiyacım var. & $11(17,7)$ \\
Aşı olma konusunda emin değilim. & $33(52,4)$ \\
HPV aşısı olmayan annelerin aşı olma konusunda istekleri (Anne, n=63) & $30(47,6)$ \\
Eğer aşı imkanım olsaydı olmak isterdim. & \\
Kararszım. & $61(96,8)$ \\
\hline HPV aşısı olma konusunda annenizin görüşü sizce nedir? (Kız Öğrenciler, n=63) & $1(1,6)$ \\
Kararı bana bırakır. & $1(1,6)$ \\
Yaptırmamı istemez. & \\
Yaptırmam konusunda beni teşvik eder. & \\
Kızınızın rahim ağzı kanserini önlemeye yönelik aşı yaptırma konusunda düşün- \\
ceniz nedir? (Anne, n=63) & $58(92,1)$ \\
Aldığı eğitimden dolayı kendi kararını kendi vermesini daha doğru buluyorum. & $5(7,9)$ \\
Yaptırması konusunda teşvik ederim.
\end{tabular}

Siz çocuk sahibi olduğunuzda çocuğunuza HPV aşısı yaptırmak ister miydiniz? (Kız

Öğrenciler, $n=63$ )

Evet

Emin değilim

Çocuklarınıza HPV aşısını yaptırdınız mı? (Anne, $n=63$ )

Evet

Hayır

\section{TARTIŞMA}

Servikal kanser kadınlarda en sık görülen kanserler arasında olup, korunma önlemleri ve risk grubundaki bireylere yapılacak tarama testleri ile görülme sıklığını ve ölüm oranlarını azaltmak son derece önemlidir. Toplumu bilinçlendirecek, eğitim ve danışmanlık verecek eğitimli hemşire ve ebelere ihtiyaç vardır (Kurt et al., 2014: 38; Kızılca Çakaloz vd., 2017;8,10). Bu çerçevede sağlık profesyoneli olmaya aday olan hemşire ve ebelik son sınıf kız öğrencileri ve annelerinin enfeksiyondan ve kanserden korunma yöntemlerinden biri olan HPV aşısı hakkındaki bilgi ve tutumları önem taşımaktadır. Çalışmaya katılan öğrenciler ve annelerinin HPV ve HPV aşısı hakkındaki bilgi ve tutumları iki bölümde tartış1lmıştır. 
International Refereed Academic Journal of Sports, Health and Medical Sciences April - May - June Issue: 31 Spring Summer Semester Year: 2019

Uluslararası Hakemli Akademik Spor Sağlık ve Tıp Bilimleri Dergisi

Nisan - Mayıs - Haziran Sayı: 31 İlbahar Yaz Dönemi Yıl: 2019 ID:436 K:528

ISSN Print: 2146-8508 Online 2147-1711

(ISO 18001-OH-0090-13001706 / ISO 14001-EM-0090-13001706 / ISO 9001-QM-0090-13001706 / ISO 10002-CM-0090-13001706) (TRADEMARK)

(2015/04315- 2015-GE-18972)

Kız Öğrenciler ve Annelerinin HPV Aşısı Hakkındaki Bilgi Durumlarına İlişkin

\section{Bulguların Tartışılması}

Çalışmaya dahil olan öğrencilerin \%87,3'ünün HPV ve \%88,9'unun HPV aşı1 hakkında bilgisinin olduğu belirlendi (Tablo 1). Ülkemizde hemşirelik ve /veya ebelik öğrencileri ile yapılan çalışmalarda öğrencilerin HPV enfeksiyonunu bilme oran $\% 55,7$ (Güvenç vd., 2012: 106), \%89,8 (Demirel Bozkurt vd., 2016:29), \%54,3 (Kızılca Çakaloz vd., 2017:13) ve HPV aşısını bilme oran1 \%90,3 (Kunt İşgüder vd., 2017:4), \%46,4 (Rathfisch et al., 2015:119) şeklinde bildirilmiştir. Ülkemizde son yıllarda yapılan ilgili çalışmaların bulguları ile çalışma bulgularımiz benzerlik göstermekte olup, HPV enfeksiyonu ve aşısı hakkında bilgisi olan hemşirelik ve ebelik öğrencilerinin oranı yüksektir. Öğrencilerin konu ile ilgili farkındalıklarının oluşması, mezuniyet sonrasında eğitim ve danışmanlık rollerine hazırlıklı olmaları açısından önemlidir.

Çalışmamıza katılan öğrencilerin \%76,2'si HPV enfeksiyonu ve aşısı ile ilgili bilgileri mesleki eğitimi sırasında edindiklerini bildirdi. Öğrencilerin edindikleri diğer bilgi kaynakları ise internet $(\% 28,6)$ sağlık personeli (doktor, hemşire vb.) $(\% 17,5)$, arkadaş-akraba $(\% 4,8)$ ve televizyon, radyo ve gazete $(\% 3,2)$ olarak belirlendi (Tablo 2). Yapilan çalışmalarda da benzer sonuçlar elde edilmiş- tir. Hemşirelik öğrencileri ile yapılan bir çalışmada birinci sınıf öğrencilerinin \%20,8'i, 2. sınıf öğrencilerinin $\% 47$ 'si, 3. sınıf öğrencilerinin \%86,6's1 ve 4. sınıf öğrencilerinin \%90,5'i HPV enfeksiyonunu daha önceden duydukları ve tüm öğrencilerin \% $\%$, 1 'inin bu bilgileri eğitimleri sırasında öğrendikleri belirtilmiştir (Güvenç vd., 2012:106). Kunt İşgüder ve arkadaşlarının (2017) yaptıkları çalışmada, birinci sınıf öğrencilerin \%25'inin, dördüncü sınıfların \%90,3'ünün HPV aşısı hakkında bilgisi olduğu bildirilmiştir. Dönmez ve arkadaşlarının (2018) hemşirelik birinci sınıf kız öğrencileri ile yaptıkları çalışmada, öğrencilerin \%17,4'ünün HPV aş1sını duydukları bildirilmiştir. Hemşirelik ve ebelik öğrencilerinin dışındaki öğrencilerde yapılan çalışmalarda bilgi kaynağı ilk sırada çoğunlukla internet ve televizyon, radyo olarak bildirilirken (Yalaki vd., 2016:89; Madhivanan et al., 2014: 109), bu çalışma ve diğer çalışma sonuçları çoğunlukla mesleki eğitim olarak bildirmektedir. Bu durum hemşirelik ve ebelik eğitiminde cinsel yolla bulaşan hastalıklar, serviks kanseri ve korunma yollar1na yönelik güncel konulara yer verildiğini göstermektedir. Ayrıca öğrencilerin \%4,8'inin bu bilgiyi arkadaş- akrabadan duymasının, birincil derecede akrabalarında serviks kanseri görülme oranı $(\% 4,8)$ ile ilişkili olduğu düşünülmektedir. 
International Refereed Academic Journal of Sports, Health and Medical Sciences April - May - June Issue: 31 Spring Summer Semester Year: 2019

Uluslararası Hakemli Akademik Spor Sağlık ve Tıp Bilimleri Dergisi

Nisan - Mayıs - Haziran Sayı: 31 İlbahar Yaz Dönemi Yıl: 2019 ID:436 K:528

ISSN Print: 2146-8508 Online 2147-1711

(ISO 18001-OH-0090-13001706 / ISO 14001-EM-0090-13001706 / ISO 9001-QM-0090-13001706 / ISO 10002-CM-0090-13001706) (TRADEMARK)

(2015/04315- 2015-GE-18972)

Literatürde hem k1z hem erkeklere uygulanabilen HPV aşısının 9-13/14 yaşları arasında iki doz, 15 yaşından sonra üç doz şeklinde yapılması önerilmektedir (WHO, 2017: 249). Çalışmaya katılan öğrencilerin \%33,3'ünün aşının kız çocuklarına, \%30,2'sinin hem kız hem de erkek çocuklarına, \%39,7'sinin 10-18 yaş arasında yapıldı ğını ifade ettikleri belirlenmiştir (Tablo 2). Yapılan çalışmalarda da öğrencilerin sirasıyla \%30,8 (Önsüz vd., 2011:559), \%26,5 (Kunt İşgüder vd., 2017:4), \%48,6 (Kızılca Çakaloz vd., 2017:12) oranında aşının sadece kızlara/kadınlara yapılabileceğini bildirdikleri belirtilmiştir. Çalışmamızda öğrencilerin yaklaşık yarısının $(\% 47,6)$ aşının kaç doz yapıldığını bilmediği ve yaklaşık onda dokuzunun aşının koruyuculuk süresini doğru bilmediği görülmüştür. Çalışma sonuçlarımızda öğrencilerin HPV enfeksiyonu ve aşısına yönelik bilgi sahibi oldukları, ancak HPV aşısının ayrıntıları (yapıldığı cinsiyet ve yaş, doz sayısı, koruyuculuk süresi) ile ilgili doğru bilginin düşük oranda olduğu söylenebilir.

Çalışmaya katılan annelerin \%88,9'unun HPV hakkında bilgilerinin olmadığı belirlenmiştir. Ancak \%9,5'inin HPV enfeksiyonun cinsel yolla bulaştığını bildikleri saptanmıştır. Thompson ve ark.'nın (2011:5-6) yaptıkları çalışmada katılımcıların \%62'sinin HPV'yi daha önce duydukları belirtilmiştir. Ortashi ve arkadaşlarının (2013: 6078) yaptıkları çalışmada 18-50 yaş arasındaki kadınların \%28,9'unun HPV enfeksiyonunu duydukları bildirilmiştir. Ghojazadeh ve ark.'nın (2012:6170) İran'da adolesanların aileleri ile yaptıkları çalışmalarında, ailelerin \%76'sının HPV hakkında bilgisi olmadığını göstermişlerdir. Ülkemizde yapılan çalışmalarda, annelerin HPV enfeksiyonu hakkında bilgisi olmama oranını Ozan ve arkadaşlar1 (2011: 147) \%66,4, Köse ve arkadaşları (2014:7264) \%88,1 ve Kürtüncü ve arkadaşları (2018:1076) \%43 şeklinde bildirmişlerdir. Ulusal ve uluslararası düzeyde yapılan çalışma bulguları ile çalışma bulgumuz paralellik göstermektedir. Çalışmada HPV hakkında bilgisi olan öğrencilerin oranı $(\% 87,3)$ kadar annelerinin bilmeme oranının $(\% 88,9)$ benzer olması dikkat çekicidir. Mezun olacak öğrencilerin öğrendikleri yeni bir bilgiyi en yakını olan anneleri ile paylaşmamaları dikkat çekici bir durumdur.

Tablo 1'de görüldüğü gibi annelerin \%15,9'unun HPV aşısı hakkında bilgisi olduğu ve \%9,5'inin bu bilgiyi sağlık personelinden aldığı belirlendi. Çalışmamızda HPV aşıs1 hakkında bilgisi olan annelerin oranının az olması olumsuz sonuçlar arasında olup, diğer çalışma bulgularını desteklemektedir. Çalışma sonucumuza benzer olarak bu çalıșmalarda da annelerin HPV aşısından haberdar olmama oran1 \%83,5 (Kose et al., 2014: 7264), \%53,7 (Bülbül ve ark. 2013:76), \%75,1 (Or- 


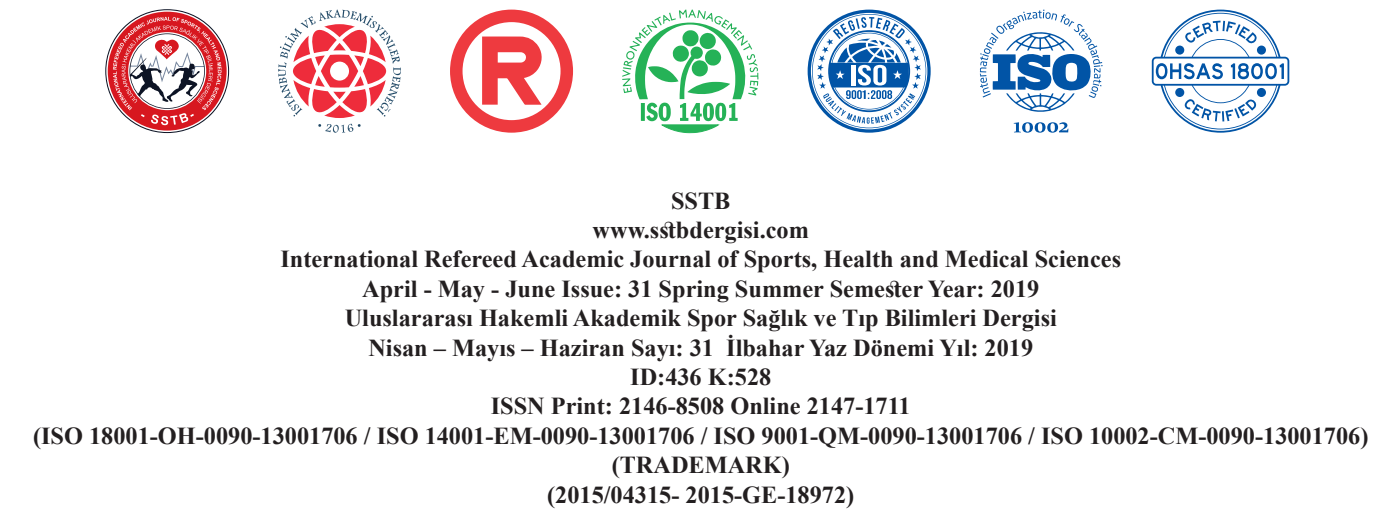

tashi et al., 2013: 6078-6079), olarak belirtilmiştir. Köse ve ark.'nın (2014:7264) 0-18 yaş arası çocuğu olan anneler ile yaptıkları çalışmada, annelerin HPV aşısı hakkındaki bilgiyi \%61,2 oranında internet, televizyon ve radyo gibi haberleşme araçlarından aldıkları bildirilmiş̧tir. Madhivanan ve arkadaşlarının (2014:109) yaptıkları çalışmada Hintli ailelerin \%86's1 doktordan, $\% 85$ 'inin televizyon ve radyodan, $\% 79$ 'unun gazeteden, \%54'ünün diğer sağlık çalışanlarından ve \%43'ünün internetten bilgiyi öğrendikleri bulunmuştur. Çalışmamızda bilgisi olan annelerin \%9,5'inin bu bilgiyi sağlık personelinden aldığı belirlendi. Araştırmalar, çocuklarının servikal kanserden korunması için HPV enfeksiyonuna karşı aşılanmasında, ebeveynin karar vermesinin önemli bir faktör olduğu vurgulanmıştır (Berenson et al., 2014:1807; Kose et al., 2014:7265) Bu nedenle aşının başarısının artmasında annelerin HPV enfeksiyonu ve aşısı ile ilgili bilgi ve tutumu önemlidir. Çalışma sonucumuzda yaklaşık on anneden sekizinin aşı hakkında bilgisinin olmadığı görülmektedir. Bu verilerle birlikte aşının ülkemizde uygulanma açısından yakın bir geçmişinin olması ve rutin aşı uygulamaları içerisinde yer almaması göz önüne alındığında; annelerin HPV enfeksiyonu ve aşısı hakkında daha ayrıntılı bilgilendirilmesi için sağlık profesyonelleri tarafindan eğitimlerin artırılması ve basın-medyada aşııın daha yaygın bir şekilde tanıtılması gerekliliği açıkça ortadadır.

Annelerin \%66,7'sinin HPV aşısının kimlere yapıldığııı, \%85,7'sinin hangi yaşta yapıldığını, \%92,1'inin aşının kaç doz yapıldığını, \%93,7'sinin koruyuculuk süresinin kaç yıl olduğunu bilmediği belirlendi (Tablo 2). Yapılan çalışmalarda da aşı hakkında spesifik bilgi konusunda ailelerin yeterli düzeyde bilgiye sahip olmadığı bildirilmiştir (Kose et al., 2014: 7265; Ghojazadeh et al., 2012: 6172; Ortashi et al., 2013:6080). Bu veriler doğrultusunda; serviks kanserinden birincil koruma sağlayan aşı hakkında toplumun bilinçlendirilmesine/ toplumun farkındalığının arttırılmasına yönelik eğitimlerin yaygın olarak devam ettirilmesi önemlidir.

Kız Öğrenciler ve Annelerinin HPV Aşısı Hakkındaki Görüş ve Tutumlarına İlişkin Bulguların Tartışııması

Çalışmaya katılan kız öğrencilerden sadece birinin $(\% 1,6)$ HPV aşısını yaptırdığı, diğer öğrencilerin $(\mathrm{n}=62)$ yaptırmadığı belirlendi. Ülkemizde yapılan çalışmalarda hemşirelik ve/veya ebelik öğrencilerinin hiç aşı yaptırmadığı (Kurt et al., 2014: 37) ya da \%0,4 (Unutkan vd., 2016: 155) \%0,8 (Kunt İşgüder vd., 2017:3-4), \%2,8 (Dönmez vd., 2018:34) oranında yaptırdığı, sağlık personellerinin \%1 (Görkem vd., 2015: 305-306) oranında HPV aşısını yaptırdıkları bulunmuştur. 


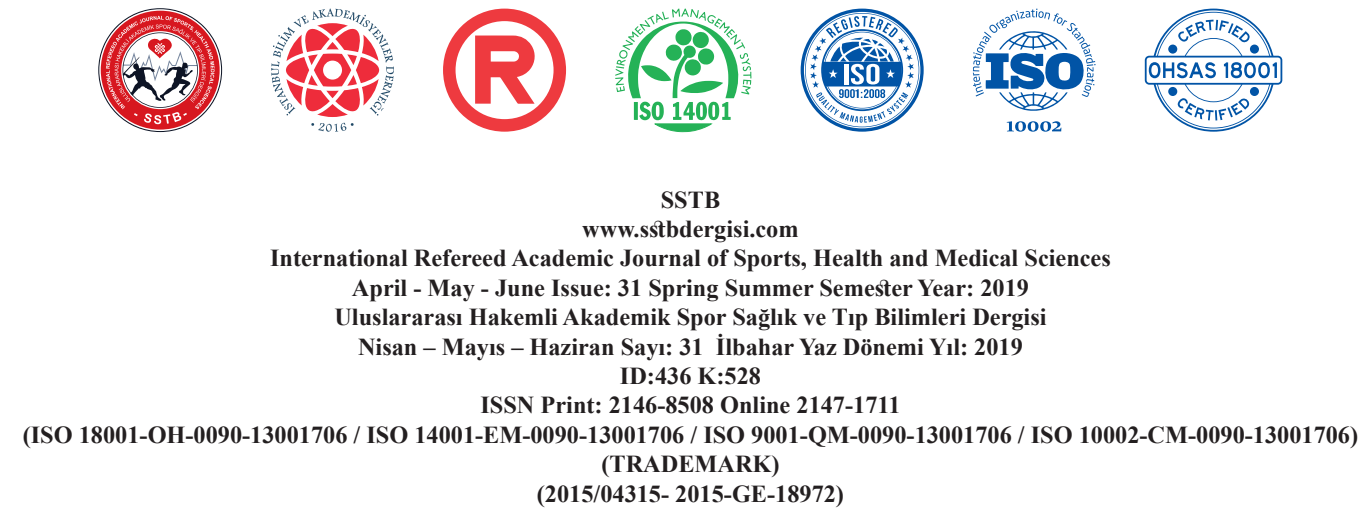

(2015/04315- 2015-GE-18972)

Mevcut çalışmalarda da çalışmamıza benzer olarak HPV aşısını yaptırmayanların oranı fazladır. Ancak diğer uluslararası çalışmalarla (Thompson et al., 2011:5-6; Tung et al., 2016: 8-9) karşılaştırıldığında ülkemizdeki hemşirelik ve ebelik öğrencilerinin aşılanma oranı azdir.

HPV aş1S1 olmayan öğrencilerin \%40,3'ünün aşıyı olmak istediklerini, \%6,5'inin eğer aşı ücretsiz olursa olmak istediğini, \%35,5'inin aşı hakkında daha fazla bilgiye ihtiyacı olduğunu ve \%17,7'sinin bu konuda emin olmadığını ifade ettikleri belirlenmiştir. Dağ ve arkadaşlarının (2015: 98-99) hemşirelik öğrencileri ile yaptıkları çalışmada, eğitim öncesi öğrencilerin \%57,5'inin HPV ve HPV aşısı ile ilgili yetersiz bilgiye sahip olduğu, eğitim sonrası öğrencilerin \%95'inin konu ile ilgili yeterli bilgiye sahip oldukları görülmüştür. $\mathrm{Bu}$ durumun aşılanan öğrenci sayısını (Eğitim öncesi: \%2,5- Eğitim Sonras1: \%30) anlamlı derece arttırdığı bildirilmiştir. Demirel Bozkurt ve ark.'nın (2016: 31) iki faklı bölgede hemşirelik öğrencileri ile yaptıkları ça1ışmada öğrencilerin \% 79,4'ünün aşı hakkında az bilgisinin olduğu, \%84,4'ünün aşı hakkında bilgi almak istediği, \%47,3'ünün aş1 olmak istediği, \%61,7'sinin ücretsiz olursa aşıyı yaptırmak istediği belirtilmiştir. Yapılan çalışmalarda aşının yaptırılmama nedenleri arasında bilgi eksikliği ve ülkemizde rutin aşı uygulaması içinde yer almamasına bağlı aşının ücretinin pahalı olması yer almaktadır (Önsüz vd., 2011: 559; Güvenç vd., 2012: 107; Tung et al., 2016; 8). Bireylerin doğru tutum ve davranışın kazanması doğru bilgi ile mümkündür (Zengin et al., 2018: 632-635). Bu doğrultuda mezuniyet öncesi öğrencilerin aşılama konusunda eksik bilgilerinin tamamlanması önerilmektedir. Ayrıca öğrencilerin üçte birinin aşı yaptırma isteğinin olması çalışma sonrasında yaklaşıma dönüşme olasıl1ğını artırması açısından sevindiricidir.

"HPV aşısı olma konusunda annenizin görüşü sizce nedir?" sorusuna öğrencilerin \%96,8'inin $(n=61)$ kararı bana birakır cevabını verdikleri belirlenmiştir. Öğrencilerin tamamına yakının aşı olma konusunda kararı ailesinin kendisine bıraktığını ifade etmesi, öğrencinin sağlıkla ilgili bir meslek okuyor ve mezun olacak dönemde olması ile ilişkili olabilir.

"Siz çocuk sahibi olduğunuzda çocuğunuza HPV aşısı yaptırmak ister miydiniz?" sorusuna öğrencilerin \% 57,1'i $(n=36)$ evet demiştir. HPV konusunda yeterli bilgisi olan sağlık personellerin aşıyı önerdikleri bildirilmiştir (Güdücü et al., 2012; 322). Çalışma bulgumuza benzer olarak bir çalışmada, hemşirelik öğrencilerinin \% 49,5'inin HPV'den korunmak için çocuklarına aşı yaptırmak istedikleri belirtilmiştir. Görkem ve ark.'nın (2015:305) Çorum'da bir üniversitesinde çalışan hemşire, ebe, fizyoterapist, anestezi 


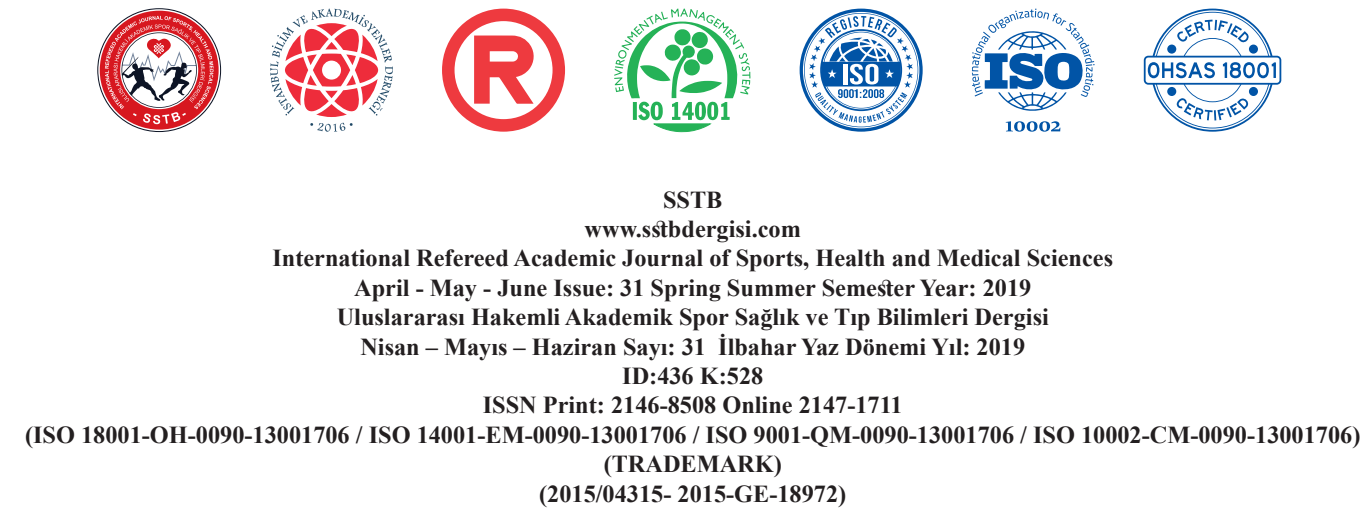

teknisyeni, radyoloji teknisyeni, laboratuvar teknisyeni ile yaptığı çalışmada, sağlık personelin \%74,5'i kızlarına HPV aşısı yaptırmak istediklerini bildirmişlerdir. Kızılca Çakaloz ve ark'nın (2017: 10-13) ebelik öğrencileri ile yaptıkları çalışmada öğrencilerin \%77,3'ünün eğer çocuk sahibi olurlarsa aşı1 çocuklarına yaptırmak istedikleri saptanmıştir.

Çalışmaya katılan annelerin tümü HPV aşısı olmadıklarını belirtmişlerdir. Eğer aşı olma imkanı olsaydı \%52,4'ü olmak istediklerini ve $\% 47,6$ 's 1 kararsız olduklarını bildirdi. K1lı̧ ve ark.'nın (2012:4270) yaptıkları çalışmada annelerin aşıyı yaptırma konusunda \%31,9'unun gönüllü olduğu, \%33,2‘sinin gönüllü olmadığ ve $\% 34,9$ 'unun kararsız olduğu bulunmuştur. Çalışma grubundaki annelerin üçte birinin aşı yaptırma konusunda gönüllü olmaması ve üçte birinin kararsız olmaları HPV $(\% 88,9)$ ve HPV aşı1s $(\% 84,1)$ hakkında yetersiz bilgiye sahip olmalarından kaynaklanıyor olabilir.

Annelere "Çocuklarınıza HPV aşısını yapturdınız mı? sorusuna sadece bir annenin $(\% 1,6)$ kız çocuğuna aşı yaptırdığını ifade ettiği belirlenmiştir. Köse ve ark.'nın (2014) yaptıkları çalışmada annelerin \%0,7'sinin kız çocuklarına aşıyı yaptırdıkları bildirilmiştir. Robitz ve ark'nın (2011:1424) Los Angeles'ta yaptıkları çalışmada annelerin \%24,6'sının kızlarına HPV aşısının en az bir dozunu yap- tırdığ 1 belirtilmiştir. Çocukların HPV aşısı ile aşılanma oranının az olduğu yapılan çalışmalarda görülmektedir.

"Rahim ağzı kanserini önlemeye yönelik kızınıza aşı yaptırma konusunda düşünceniz nedir?" sorusuna annelerin \%92,1'inin aldığı eğitimden dolayı kararını kendisinin vermesini daha doğru bulduğu, \%7,9'unun yaptırması konusunda teşvik ettiği bulunmuştur. Annelerin, özellikle HPV aşıları konusunda, çocuklarının sağlık kararlarına oldukça fazla katıldığı gösterilmiştir (Berenson et al., 2014: 1808). Ülkemizde yapilan çalışmalarda; annelerin \%45,5'inin (Kılıç vd., 2012:4270), \%49'unun (Kürtüncü vd., 2018: 1079), uluslararası yapılan bir çalışmada annelerin \%64,2'sinin (Robitz et al., 2011: 1424) kızlarına HPV aşısı yaptırma konusunda gönüllü oldukları bulunmuştur. İncelenen çalışmalarda annelerin yaklaşık yarısının aşı yaptırma konusunda istekli olmasına karşın, çalışma sonucumuzda annelerin HPV ve servikal kanserden korunmaya yönelik aşılanma kararını kızlarına bırakmaları, kızlarının bilgisine ve aldıkları mesleki eğitime güvendiklerini düşündürmektedir.

\section{SONUÇ}

Öğrencilerin HPV ve HPV aşısı hakkında doğru bilgiye sahip olmaları konu ile ilgili farkındalıklarının olması ve mezuniyet sonrasında eğitim ve danışmanlık rollerine ha- 
International Refereed Academic Journal of Sports, Health and Medical Sciences April - May - June Issue: 31 Spring Summer Semester Year: 2019

Uluslararası Hakemli Akademik Spor Sağlık ve Tıp Bilimleri Dergisi

Nisan - Mayıs - Haziran Sayı: 31 İlbahar Yaz Dönemi Yıl: 2019 ID:436 K:528

ISSN Print: 2146-8508 Online 2147-1711

(ISO 18001-OH-0090-13001706 / ISO 14001-EM-0090-13001706 / ISO 9001-QM-0090-13001706 / ISO 10002-CM-0090-13001706) (TRADEMARK)

(2015/04315- 2015-GE-18972)

zırlıklı olmaları kendi sağlıkları başta olmak üzere aşıyı topluma önermeleri açısından önemlidir. Kız öğrencilerin annelerinin HPV ve HPV aşısı hakkındaki bilgilerinin yeterli olmadığı saptandı. Öğrencilerin büyük çoğunluğunun HPV ve HPV aşısı hakkındaki bilgiyi mesleki eğitim sırasında aldığı, ancak öğrencilerin yaklaşık yarısının aşı hakkında daha fazla bilgiye ihtiyaçlarının olduğu, beş öğrenciden birinin de aşı hakkında emin olamadıkları belirlenmiştir. Konu ile ilgili bilgiye sahip annelerin bilgiyi sağlık personelinden aldı ̆̆ sadece bir öğrenci olduğu saptand1. Annelerin aşı konusunda karar verme sürecini aldıkları eğitimden dolayı kızlarına bıraktıkları belirlendi.

Bu çalışmanın güçlü yönü, ulusal alanda hem aşılama yaş grubunda olan hem de sağlık ile ilgili bir meslek eğitimi alan hemşirelik ve ebelik son sınıf kız öğrencileri ve annelerinin HPV aşılaması hakkında bilgi, görüş ve tutumlarının birlikte ele alınmış olmasıdır. Bu nedenle çalışmanın sonuçları önemlidir. HPV aşısı ile ilgili farklı örneklem grupları ile daha kapsamlı çalışmalar yapılması önerilebilir.

\section{KAYNAKÇA}

BERENSON, A.B., LAZ, T.H., HIRT, J.M., MCGRATH, J.C., RAHMAN, M., (2014). Effect of the decision-making process in the family on HPV vaccina- tion rates among adolescents 9-17 years of age. Hum Vaccin Immunothe, 10 (7): 1807-1811.

BRAY, F., FERLAY, J., SOERJOMATARAM, I., SIEGEL, R.L., TORRE, L.A., JEMAL, A., (2018). Global Cancer Statistics 2018: GLOBOCAN Estimates of Incidence and Mortality Worldwide for 36 Cancers in 185 Countries. Ca Cancer J Clin, 68: 394-424

BRUNI, L., ALBERO, G., SERRANO, B., MENA, M., GÓMEZ, D., MUÑOZ, J., BOSCH, F.X., et al., (2018). ICO/IARCvInformation Centre on HPV and Cancer (HPV Information Centre). Human Papillomavirus and Related Diseases in Americas. Summary Report 10 December 2018. [02.January 2019]

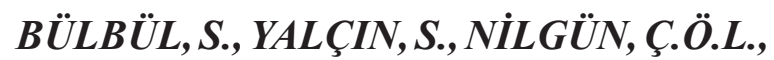
TURGUT, M., EKICİ, İ., DOĞAN, A., YELTEKİN, S., (2013). Anadolu'da 0-15 yaş çocuk annelerinin rahim ağzı kanseri ve Human Papilloma Virüs aş1laması hakkındaki düşünceleri. Türkiye Çocuk Hastalıkları Dergisi, 7(2):73-78.

DAĞ, H., DÖNMEZ, S., SEZER, H., ŞEN-

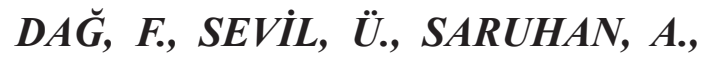
(2015). The effects of two different teaching techniques on the knowledge level of nursing students about HPV. Gaziantep Medical Journal, 21(2), 90-98. 
International Refereed Academic Journal of Sports, Health and Medical Sciences April - May - June Issue: 31 Spring Summer Semester Year: 2019

Uluslararası Hakemli Akademik Spor Sağlık ve Tıp Bilimleri Dergisi

Nisan - Mayıs - Haziran Sayı: 31 İlbahar Yaz Dönemi Yıı: 2019 ID:436 K:528

ISSN Print: 2146-8508 Online 2147-1711

(ISO 18001-OH-0090-13001706 / ISO 14001-EM-0090-13001706 / ISO 9001-QM-0090-13001706 / ISO 10002-CM-0090-13001706) (TRADEMARK)

DEMIREL BOZKURT, Ö., HADIMLI, A., ŞEN, E., IKKTE ÖNER, E., ÖZTÜRK CAN, H., (2016). Hemşirelik öğrencilerinin Human Papilloma Virüs (HPV) enfeksiyonu ve aşısına yönelik bilgi ve görüşleri: Bölgesel farklılıklar. Uluslararası Hakemli Kadın Hastalıkları ve Anne Çocuk Sağlı̆̆ı Dergisi, 5: 23-48

DONMEZ, S., OZTURK, R., KISA, S., KARAOZ, W.B., ZEYNELOGLU, S., (2018). Knowledge and perception of female nursing students about human papillomavirus (HPV), cervical cancer, and attitudes toward HPV vaccination, Journal of American College Health,6: 1-8

GLOBOCAN, (2012). International Agency for Research on Cancer, World Health Organization.-estimated cancer incidence, mortality and prevalence worldwide in 2012. http://globocan.iarc.fr/Default. aspx (accessed December 1, 2018)

GHOJAZADEH, M., NAGHAVI-BEHZAD, M., AZAR, Z.F., SALEH, P., GHORASHI, S., POURI, A.A., (2012). Parental knowledge and attitudes about papilloma virus in Iran. Asian Pac J Cancer Prev, $13,6169-73$

GÖRKEM, ̈̈., TOĞRUL, C., INNAL, H.A., SALMAN-ÖZG̈̈, B., GÜNGÖR, T., (2015). Üniversite hastanesinde çalışan yardımcı sağlık personelinin Human Pa- pilloma Virüs ve aşısı hakkında bilgi düzeyleri ve tutumları. Türk Hijyen ve Deneysel Biyoloji Dergisi, 72(4); 303-310

GUDUCU, N., GONENC, G., ISCI, H., YIGITER, A.B., DUNDER, I., (2012). Awareness of human papilloma virus, cervical cancer and HPV vaccine in healthcare workers and students of medical and nursing schools. Journal of Clinical \& Experimental Investigations/Klinik ve Deneysel Araştırmalar Dergisi, 3(3): 318-325

GÜVENÇ, G., AKYÜZ, A., SEVEN, M., (2012). Hemşirelik yüksek okulu öğrencilerinin human papilloma virüs enfeksiyonu ve aşıları ile ilgili bilgi ve tutumlarının belirlenmesi. Gülhane Tıp Derg., 54:104-110

KILIC, A., SEVEN, M., GUVENC, G., AKYUZ, A., CIFTCI, S., (2012). Acceptance of human papillomavirus vaccine by adolescent girls and their parents in Turkey. Asian Pac J Cancer Prev, 13, 426772

KIZILCA ÇAKALOZ, D., ÖZTÜRK, G., ÇOBAN, A., KARAÇAM, Z., (2017). Ebelik Öğrencilerinin Servikal Kanser ve HPV Aşısı Hakkında Bilgi ve Düşüncelerinin Belirlenmesi. Adnan Menderes Üniversitesi Sağlık Bilimleri Fakültesi Dergisi, 2(2): 8-17 
International Refereed Academic Journal of Sports, Health and Medical Sciences April - May - June Issue: 31 Spring Summer Semester Year: 2019

Uluslararası Hakemli Akademik Spor Sağlık ve Tıp Bilimleri Dergisi

Nisan - Mayıs - Haziran Sayı: 31 İlbahar Yaz Dönemi Yıl: 2019 ID:436 K:528

ISSN Print: 2146-8508 Online 2147-1711

(ISO 18001-OH-0090-13001706 / ISO 14001-EM-0090-13001706 / ISO 9001-QM-0090-13001706 / ISO 10002-CM-0090-13001706) (TRADEMARK)

KOSE, D., ERKORKMAZ, U., CINAR, N., ALTINKAYNAK, S., (2014). Mothers' knowledge and attitudes about hpv vaccination to prevent cervical cancers. Asian Pacific Journal of Cancer Prevention, 15 (17): 7263-7266

KUNT ISSGÜDER, Ç., OKTAY, G., DOĞRU, H. Y., DELİBAŞ, I.B., ÖZSOY, A.Z., YILDIZ ÇELTEK, N., BULUT, Y.E., (2017). Sağlık yüksek okulu öğrencilerinin HPV aşısı bilgi düzeyinin değerlendirilmesi. J Contemp Med, 7(1): 1-7

KURT, R., KARATEKE, A., ERDEM, M., BENK SILFELER, D., AKKOCA, A.N., SOYLU KARAPINAR, O., et al., (2014). Human Papilloma Virus and HPV vaccine knowledge among Mustafa Kemal University Medical Students. Acta Med Anatol, 2(2):37-41

KÜRTÜNCÜ, M., ARSLAN, N., ALKAN, I., BAHADIR, Ö., (2018). 10-15 yaş aras1 k1z çocuğu olan annelerin rahim ağz1 kanseri ve HPV aşısı konusunda bilgi, tutum ve davranışları. Journal of Human Sciences, 15(2): 1072-1085

MADHIVANAN, P., SRINIVAS, V., MARLOW, L., MUKHERJEE, S., NARAYANAPPA, D., MYSORE, S., ET AL. (2014) Indian parents prefer vaccinating their daughters against HPV at older ages. Asian Pac J Cancer Prev, 15 (1): 107-10
ORTASHI, O., RAHEEL, H., SHALAL, M., OSMAN, N., (2013). Awareness and knowledge about human papillomavirus infection and vaccination among women in UAE. Asian Pac J Cancer Prev, 14, 6077-80

OZAN, H., DEMIR, B. Ç., ATIK, Y., G̈̈MÜŞ, E., ÖZERKAN, K., (2011). Kadın hastalıkları ve doğum polikliniğine başvuran hastaların Human Papilloma Virüs ve HPV aşısı hakkındaki bilgi düzeylerinin belirlenmesi. Uludağ Üniversitesi Tıp Fakültesi Dergisi, 37(3): 145-148

ÖNSÜZ, F.M., TOPUZOĞLU, A., (2011). Bir tıp fakültesinde kadın hastalıkları ve doğum stajını yapmış öğrencilerin HPV aşısı hakkında bilgi düzeyleri ve tutumlarının değerlendirilmesi. Taf Prev Med Bull, 10, 557-64

PRINTZ, C., (2015). FDA approves Gardasil 9 for more types of HPV. Cancer, 121(8):1156-1157

RATHFISCH, G., GUNGOR, I., UZUN, E., KESKIN, O., TENCERE, Z., (2015). "Human Papillomavirus Vaccines and Cervical Cancer: Awareness, Knowledge, and Risk Perception Among Turkish Undergraduate Students" Journal of Cancer Education, 30: 116-123 
International Refereed Academic Journal of Sports, Health and Medical Sciences April - May - June Issue: 31 Spring Summer Semester Year: 2019

Uluslararası Hakemli Akademik Spor Sağlık ve Tıp Bilimleri Dergisi

Nisan - Mayıs - Haziran Sayı: 31 İlbahar Yaz Dönemi Yıl: 2019 ID:436 K:528

ISSN Print: 2146-8508 Online 2147-1711

(ISO 18001-OH-0090-13001706 / ISO 14001-EM-0090-13001706 / ISO 9001-QM-0090-13001706 / ISO 10002-CM-0090-13001706) (TRADEMARK)

ROBITZ, R., GOTTLIEB, S.L., DE ROSA, C.J., GUERRY, S.L., LIDDON, N., ZAIDI, A., et al., (2011). Parent attitudes about school requirements for human papillomavirus vaccine in high-risk communities of Los Angeles, California. Cancer Epidemiol Biomarkers Prev, 20, 1421-29

T.C. SA ĞLIK BAKANLIĞI., (2018). TC Sağlık Bakanlığı Türkiye Halk Sağlığı Kurumu.Türkiye Kanser İstatistikleri 2015, Ankara, 2018

THOMPSON, V.L.S., ARNOLD, L.D., NOTARO, S.R., (2011). African American parents' attitudes toward HPV vaccination. Ethn Dis, 21, 335-41

TEZER, H., YÜKSEK, S.K., (2013). Human Papilloma Virüs Aşıları (İçinde) Pratik Aş1 Bilgileri, (Ed.) E. Hasanoğlu, Güneş Tip Kitabevleri, Ankara. pp:89-92

TUNG, I.L.Y., MACHALEK, D.A., GARLAND, S.M., (2016). Attitudes, knowledge and factors associated with human papillomavirus (hpv) vaccine uptake in adolescent girls and young women in Victoria, Australia. PLoS ONE 11(8): e 0161846
UNUTKAN, A., BALCI YANGIN, H., (2016). Üniversite öğrencilerinin human papilloma virus aşısına ilişkin bilgi ve görüşlerinin değerlendirilmesi. TAF Prev Med Bull, 15 (2): 151-158

WORLD HEALTH ORGANIZATION (WHO). (2017). Weekly epidemiological record. 92 (19): 241-268

YALAKI, Z., TAŞAR, M.A., UNSAL SAC, R., GOCMEN, S., KARADA $\breve{G L I, ~ S ., ~ A K-~}$ $B A S$, , N., VE DIGG., (2016). Lisede okuyan öğrencilerin insan papilloma virüs enfeksiyonu hakkındaki bilgi düzeyleri. J Pediatr Inf, 10: 86-92

ZENGIN, H., MENEKSE, D., CINAR, N., (2018). Risky Behaviours in Adolescence. The Most Recent Studies in Science and Art. (Eds: H. Arapgırlığlu, A.Atık, S.Hızıroğlu, R. L.Elliott, D.Atık) Volume 1, Gece Kitaplığı, Ankara.p.632-649

TESEKKÜR: Calısmava katılan tüm hemsirelik ve ebelik öğrencilerine ve annelerine tesekkür ederiz.

YAZAR NOTU: Bu calısma 1. Uluslararast Kadın Cocuk Săğlı̆̆l ve Eğitimi Kongresi, 14-15 Nisan 2016, Kocaeli'de sözel bildiri olarak sunulmustur. 


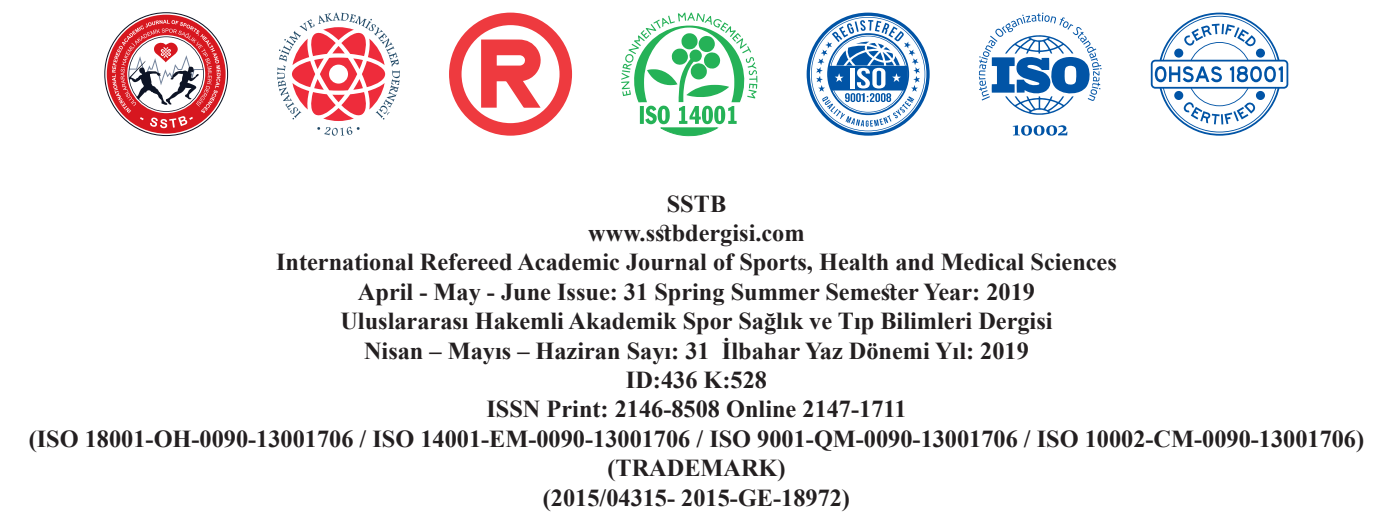

\section{EXTENDENT ABSTRACT}

Introduction: Cervical cancer is the third most common gynecologic cancer in the world. Cervical cancer, one of the preventable diseases, is one of the major public health problems. Human Papilloma virus (HPV), one of the common sexually transmitted infections, causes cervical cancer. Along with cervical cancer prevention methods, HPV awareness and prophylactic vaccine administration significantly decrease the cervical cancer incidence and deaths. The most important factor in the administration of HPV vaccine and the acceptance of the vaccine by the public is undoubtedly health professionals. Studies indicate that the fact that the health personnel support and recommend HPV vaccines is the main reason that increases the acceptability of the vaccine. On the other hand, the success of the vaccine depends on the decisions on vaccination of individuals or families who are eligible for vaccination. In particular, mothers' basic knowledge about the disease and vaccination is the main factor for the success of the vaccination program. Aim: This study was carried out to determine the knowledge and attitudes of final year female students of a Vocational Health High School and their mothers on Human Papilloma Virus (HPV) Vaccination. Material - Method: All $4^{\text {th }}$ grade female students studying in the nursing and midwifery department of a vocational health high school in Sakarya Province during the 2014-2015 spring term constituted the population of the study which was designed as a descriptive search. 144 students were studying in the final year of their degree on the dates during which the study was carried out. The sample was not calculated and it was aimed to reach the entire population. 63 female students and their mothers who agreed to participate in the study and filled out the questionnaire forms properly and completely and delivered them to the researcher were included in the study (Participation rate: 43.75\%). Before starting the application, written permission was obtained from the institution where the study was carried out. Data were collected using the student questionnaire form and mother questionnaire form developed by the researchers, by reviewing the relevant literature. The student questionnaire form consisted of a total of 19 questions including 6 questions including socio-demographic information (age, department studied, marital status, employment status, economic situation etc.) and 13 questions determining the students' knowledge and attitudes about the HPV vaccine (knowing the HPV vaccine, at how many doses, to whom and at what age the vaccine will be administered, duration of protection, etc.). The mother questionnaire form consisting of a total of 26 questions included 6 questions related to socio-demographic information and 20 questions related to knowledge and attitudes about HPV (hearing HPV vaccine and taking the HPV vaccine, 


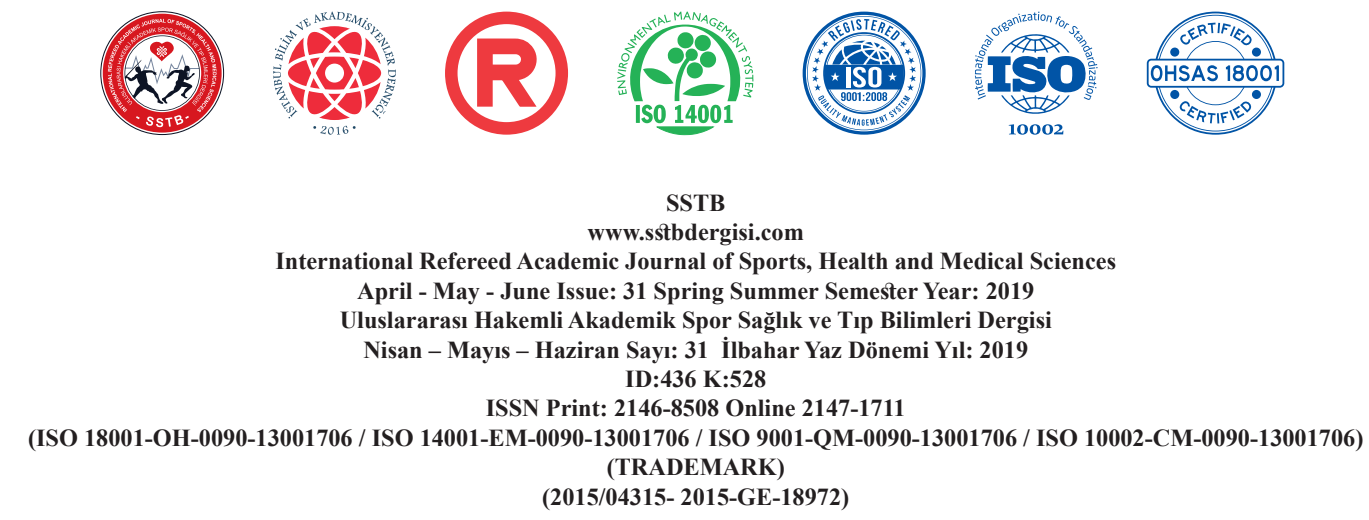

at what age and to whom the vaccine will be administered, state of making their children get vaccinated, etc.). Before the data were collected, the students were informed about the aim of the study and the questionnaire form and their verbal approvals were obtained. The numbers of the student questionnaire form and the mother questionnaire form were matched with the same number, and the student questionnaire form was distributed. Students completed the questionnaire form in the classroom environment. The process of filling out the questionnaire form of the students lasted for 10 minutes. The voluntary consent form and the questionnaire form were sent to mothers through their daughters with the sealed envelope method. Mothers filled out the questionnaire form and sent to the researchers in a sealed envelope. Data collection was completed between February 2015 and April 2015. The data obtained were evaluated using percentage and mean in the computer environment. Findings and Results: All of the students participating in the study were female, and it was determined that $69.8 \%$ of them $(n=44)$ were nursing department student, $30.2 \%$ of them $(\mathrm{n}=19)$ were midwifery department students, and the average age was $21.65 \pm 0.91(\min =20, \max =25)$. It was found that $90.5 \%$ of the students $(n=57)$ did not work, $98.4 \%$ of them $(n=62)$ were single and $66.7 \%$ of them $(n=42)$ had a moderate economic situation. The average age of the mothers of female students participating in the study was $46.78 \pm 5.74(\min =36 \max =59)$. It was found that $73 \%$ of the mothers $(n=46)$ were primary school graduates and $88.9 \%$ of them $(n=56)$ did not work. $4.8 \%$ of the students $(n=3)$ reported that their first degree relatives had cervical cancer. $87.3 \%$ of the students $(n=55)$ reported that they had knowledge about HPV, $88.9 \%$ of them $(n=59)$ reported that they had knowledge about HPV vaccine and mostly received this knowledge from the high school where they are studying, and $76.2 \%$ of them $(n=48)$ reported that they received knowledge during their vocational education. It was determined that other knowledge sources were internet $(28.6 \%, \mathrm{n}=18)$ healthcare personnel (doctor, nurse, etc.) $(17.5 \%, \mathrm{n}=11)$, friend-relative $(4.8 \%, \mathrm{n}=3)$ and television, radio and newspaper $(3.2 \%, n)=2)$. While $33.3 \%$ of the students $(n=21)$ stated that the vaccine was administered to female children, $30.2 \%$ of them $(n=19)$ stated that it was administered to both female and male children, and $39.7 \%$ of them $(n=25)$ stated that it was administered between the ages of $10-18$ years. (Table 1$) 31.7 \%$ of the students $(n=20)$ reported that the vaccine was administered at 3 doses in total. It was determined that $12.7 \%$ of them $(n=8)$ correctly knew the duration of protection of the vaccine. It was determined that $1.6 \%$ of the female students participating in the study $(n=1)$ had HPV vaccination while $98.4 \%$ of them $(n=62)$ did not have. $39.7 \%$ of those who did not have HPV vaccine stated that they wanted to be vaccinated, $6.3 \%$ of them $(n=4)$ stated that they wanted to be vaccinated if the vaccine would free, $34.9 \%$ 


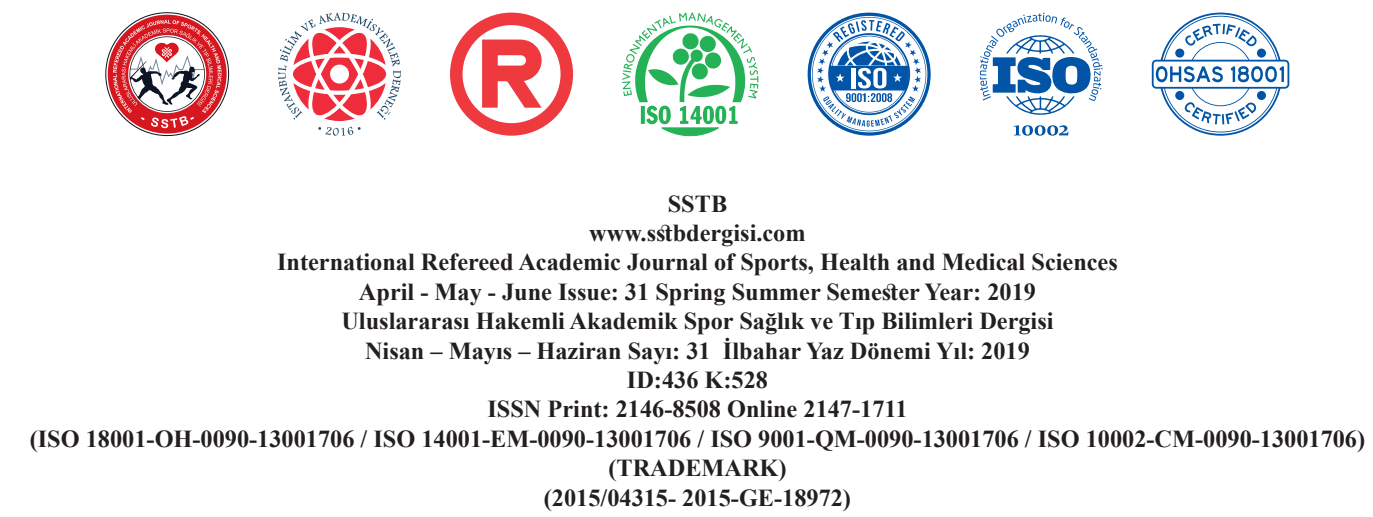

of them $(n=22)$ stated that they needed more knowledge about the vaccine, and $17.5 \%$ of them $(n=11)$ stated that they were not sure about it. With respect to the question "What do you think is your mother's opinion about getting HPV vaccine?", $96.8 \%$ of the students $(n=61)$ mostly answered that she leaved me the decision. $57.1 \%$ of the students $(n=36)$ answered the question "Would you like to have HPV vaccine for your child when you have children?" yes. While $77.8 \%$ of the mothers $(n=49)$ stated that they had previously heard of pap smear, $6.3 \%$ of them $(n=4)$ stated that cervical cancer was present in their families and immediate surroundings and that $4.8 \%$ of them $(n=3)$ and $1.6 \%$ of them $(n=1)$ were first degree relatives and second-degree relative, respectively. While $11.4 \%$ of the mothers participating in the study $(n=7)$ reported that they had knowledge about HPV, 9.5\% of them $(n=6)$ reported that HPV infection was transmitted sexually. While $15.9 \%$ of the mothers $(n=10)$ indicated that they had knowledge about HPV vaccine, $9.5 \%$ of those with knowledge $(n=6)$ stated that they obtained this knowledge from health personnel, and $3.2 \%$ of them $(n=2)$ and $3.2 \%$ of them $(n=2)$ stated that they obtained this knowledge from television, newspaper and radio and from relatives - friends, respectively. It was determined that mothers did not know to whom HPV vaccine is administered by $87.3 \%$ $(n=55)$, at what age it is administered by $92.1 \%(n=58)$, how many doses the vaccine is administered by $95.4 \%$, and the duration of protection of the vaccine by $96.9 \%(n=61)$. All of the mothers participating in the study stated that they did not have HPV vaccine. $52.4 \%$ of them ( $\mathrm{n}=$ 33) stated that they wanted to be vaccinated and $47.6 \%$ of them $(n=30)$ stated that they were undecided if there was the possibility of being vaccinated. The mothers were asked the question "Have you made your children get the HPV vaccine?", and one of the mother stated that she made her female child get the vaccine by $1.6 \%(n=1)$. For the question "What do you think about your daughter's vaccination to prevent cervical cancer?", mothers mostly, $92.1 \%$ of them $(n=58)$, answered that I find it more appropriate to make her own decision due to the education she has received. It was determined that the knowledge of the mothers of female students about HPV and HPV vaccine was not adequate. The vast majority of students stated that they received information about HPV and HPV vaccine during their vocational education. However, it was determined that nearly half of the students needed more information about the vaccine and that 1 of 5 students was not sure about the vaccine. It was found that the mothers with knowledge about the subject received the knowledge from the health personnel. For the sample group, the rate of vaccinated students was found to be $1.6 \%$. It was determined that the mothers left the decision on vaccine to their daughters due to the education they received. 